\title{
Drum Seeder Technology is Made Easy Paddy Cultivation and it is a Boon to Farmers of North Coastal Zone of Andhra Pradesh
}

\author{
M. M. V. Srinivasa Rao ${ }^{1 *}$ and D. Chinnam Naidu ${ }^{2}$ \\ District Agricutral Advisory \& Transfer of Technology Centre(DAATTC), \\ Amadalavalasa, Srikkulam District, Andhra Pradesh, PIN-535 001, India \\ Acharya N. G. Ranga Agricultural University, India
}

*Corresponding author

\section{A B S T R A C T}

\begin{tabular}{|l|}
\hline Ke y w o r d s \\
Paddy drum seeder, \\
Cono Weeder, OFT, \\
Yield, B:C Ratio. \\
\hline Article Info \\
\hline $\begin{array}{l}\text { Accepted: } \\
\text { 18 August } 2019 \\
\text { Available Online: } \\
\text { 10 September } 2019\end{array}$ \\
\hline
\end{tabular}
Cono Weeder, OFT, Yield, B:C Ratio.

Accepted: Available Online: 10 September 2019
In srikakulam district of andhra pradesh, paddy is major important crop during kharif cultivated in an area of 2,01,148 ha out of total cropped area of 2,66,433 ha with productivity of $4587 \mathrm{~kg} / \mathrm{ha}$. In the district, traditional method of paddy cultivation, adoption of more seed rate, late transplanting with over aged seedlings, close spacing coupled with scarcity of labour and escalation in labor wages, reduction in labor efficiency are leading to lower yields and low net returns, besides that farmers are distressed to cultivate paddy. Farmers are searching for new and easy technology to cultivate the paddy. With the feedback from farmers scientists from DAATT Centre also searched for easy and best technology. Finally we identified the paddy drum seeder technology in consultation with Indian Institute of Rice Research, Rajendranagar, Hyderabad scientists, which is very easy and less labour involved. Drum seeder technology is boon to farmers to save money and time and receive crop harvest 7-10 days earlier than normal transplanted field. DAATT Centre, Srikakulam District of ANGRAU, in collaboration with Department of Agriculture, Srikakulam District has introduced 'Paddy Drum Seeder Technology' through organizing On-Farm Demonstrations (OFDs) since Kharif, 2011. With help of NABARD "Project on Direct Sowing of Paddy with 8 Row Paddy Drum Seeder" supported under Farmers' Technology Transfer Fund (FTTF) for three years, 2011-12,2012-13 \& 2013-14. On Farm Demonstrations were conducted in 5 locations during Kharif season on paddy drum seeder cultivation in Srikakulam District. In general Soils of Srikakulam District are low in organic carbon, low to medium in Phosphorus, medium to high in potassium. Yield in paddy drum seeder technology recorded $12.49 \%$ yield over normal method of paddy cultivation during Kharif season. The results from the study showed that the farmers realized the $40.42 \%$ increase in net income due to increased grain yield by $12.49 \%$ with reduction of cost of cultivation by $14.23 \%$, it could be attributed to reduction in manual labour, it could be attributed to reduction in manual labour of 15 man labour and 32 women labour and also increase in yield attributes and yield and also increase in yield attributes and yield. 


\section{Introduction}

Rice area has been decreasing in state like Andhra Pradesh, although overall productivity is increasing, there is a decrease in compound growth rate in rice productivity at national level (Krishnaiah 1999). There is no scope for expansion of area for rice cultivation. Rice yields are plateau in the irrigated ecosystem and the rainfed system with low productivity of 2.5 to $3.5 \mathrm{t} / \mathrm{ha}$.

Since the frontier of horizontal expansion of rice area has already been closed, it has become imperative to increase rice production per unit area per unit time to feed the teaming millions in the new millennium. India has to produce 135-145 million tones by 2020 A.D. to feed the additional 350million people. To do so, the productivity should be raised to $3.2 \mathrm{t} / \mathrm{ha}$ by $2020 \mathrm{AD}$ from the present level of 2.05t/ha.(The Hindu Survey of Indian Agriculture). To achieve this task we have to increase the productivity of rice with planning and strategy. To meet this challenge national resource base should be used in the best possible way to increase and sustain productivity. All inputs should be used judiciously to achieve higher inputs use efficiency simultaneously reducing the cost of cultivation.

The problem and challenges facing rice cultivation at present are quite different from the past, that have been effectively tackled during the previous years. To combat the situation in recent years, rice farmers are blessed with advanced technology and knowledge of paddy drum seeder technology to achieve potential benefits through increased yields with reduced cost of cultivation.

In Srikakulam District of Andhra Pradesh, paddy is predominant crop during kharif cultivated in an area of 2,01,148 ha out of total cropped area of 2,66,433 ha with productivity of $4587 \mathrm{~kg} / \mathrm{ha}$. Total irrigated area is $1,89,648$ ha and main irrigation sources are channels, tanks and bore wells. In the district traditional method of paddy cultivation involving adoption of more seed rate, late planting with over aged seedlings and close spacing coupled with scarcity of labour and escalation in labour wages are leading to lower yields and low net returns.

Srikakulam district is the one of the rice growing districts in Andhra Pradesh. Farmers grow rice in 2.0 lakh ha during Kharif and 6000 ha during Rabi. Cost of cultivation is rising year by year due many reasons i.e social reasons, situational factors and input cost. At present cost of cultivation per acre is between Rs12500/- to Rs 15000/-. This is mainly due increase in labour wages and scarcity of labour in villages for agricultural operations, and increase in price of fertilizers.

To overcome this, paddy drum seeder technology is boon to farmers to save money and time and receive quality crop harvest at 7 10 days earlier than normal transplanted field. Paddy drum seeder technology holds special significance in the present day production system with regard to saving labour component by $30-50 \%$ and increase the productivity by 20-30\% (Annual Reports of Indian Institute of Rice Research, 2003, Rajendranagar, Hyderabad).

Paddy drum seeder technology, a new way of cultivation is gaining more attention of the farmers in Srikakulam District. But the paddy drum seeder technology has its own implications to adopt such as right choice of field, irrigation facilities, varieties, land preparation, weed management and machinery available.

The prime concern of any programme related to agriculture is to enhance productivity and with reduced cost. In order to reduce the cost 
of cultivation DAATTC Srikakulam took initiatives in collaboration with NABARD to promote direct seeding of paddy with drum seeder in Srikakulam district.

\section{Objectives}

To introduce and test the feasibility of paddy drum seeder technology in the Srikakulam District through On Farm Trials(OFTs), Method demonstrations and Group discussions.

To record the yield in paddy drum seeder technology in comparison with normal method to convince the farmer. To analyze the economics of paddy cultivation in Srikakulam District.

\section{Materials and Methods}

Scientists in DAATT Centre, Srikakulam District of ANGRAU in collaboration with Department of Agriculture, Srikakulam District and with funding from NABARD under supported under Farmers' Technology Transfer Fund (FTTF), has introduced paddy drum seeder technology with comparing normal method of cultivation through organizing On-Farm Trials (OFTs) since Kharif, 2011 in 5 locations.

\section{Details and advantages of Direct Paddy Seeder technology}

Direct Paddy Drum Seeder(Fig.1) is small equipment for sowing germinated paddy seed directly in wetland field is fabricated and it is used for demonstration. There is no need for transplantation.

It is a manually pulled implement. It covers 8 rows of $20 \mathrm{~cm}$ row-to-row spacing at a time. It is made up of plastic materials. Cono weeder (Fig.2) is used for intercultivaton to incorporate weed in inbetween rows apart of $20 \mathrm{~cm}$.

\section{Salient Features}

Labour cost is reduced drastically

Cost of cultivation is reduced because, cost on nursery raising, nursery pulling and transplanting can be saved

Uniformity in seed sowing and Plant population

Continuous drilling of seeds is eliminated.

Reduction in seed rate and thinning cost. Crop matures 7-10 days earlier than the transplanted paddy Light in weight and easy to handle. An area of 1 hectare per day can be shown

Saving in seed requirements: $12-18 \mathrm{~kg}$ per acre is sufficient depending on variety

Farmer fields are selected with proper drainage facility and regulation of water, to conduct On Farm Trials (OFTs). The varieties cultivated in paddy drum seeder technology were MTU-1001, MTU-1010, MTU-7029, MTU-1075 and BPT-5204.

Since planting of crop in both Drum seeder technology and Normal method data pertaining to crop stand with number of tillers per hill, number of tillers per square meter, incidence of pests and diseases if any at regular intervals followed by yield contributing parameters like effective tillers, panicles per hill \& square meter, length and texture of panicle, number of grains per panicle and 1000 grain weight are recorded. Yield per $5 \times 5 \mathrm{~m}^{2}$ was collected and calculated per hectare area. Means of yield attributes, yield and cost of cultivation were arrived for yield in both drum seeder technology and normal transplanting methods. Percentage yield increase over normal method was calculated and comparative analysis of cost benefit ratio per hectare was arrived and presented in the tables. 


\section{Results and Discussion}

In Srikakulam District since Kharif-2011 the On-Farm Demonstrations on Drum seeder technology is conducted for three Kharif seasons in innovative farmers fields and yield attributes and yield are depicted in following tables.

\section{Crop duration}

The duration of the crop (Table.1)is recorded, it was observed that there is reduction of duration to reach the harvesting of rice crop was observed. The reduction of crop duration is 14 days was observed when compared to normal transplantation method of rice cultivation.

\section{Yield Attributes}

All yield attributes, during all the years were

Fig.1 Drum seeder

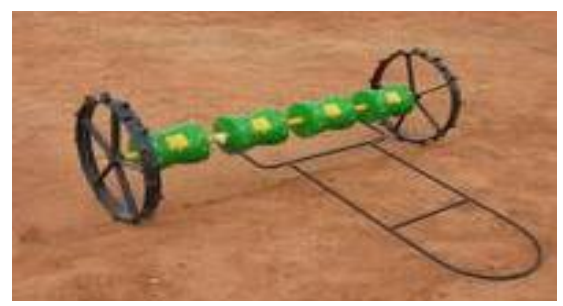

recorded better in Drum seeder technology than normal method(Table.1). During all kharif seasons in all the locations with different varieties recorded the number of productive tillers per/Sq.mt, and number of grains per panicle are 267 and 233 respectively are more than normal practice 220 and 202(MSSRF,2002).

\section{Yield}

Grain yield (Table.1)increase was achieved to a tune of $12.49 \%$ in drum seeder method (6275 $\left.\mathrm{kgha}^{-1}\right)$ over normal method of cultivation (55786 $\left.\mathrm{kgha}^{-1}\right)$. Higher yield in drum seeder technology is contributed by more number of productive tillers by supported by profuse root system resulted in more number of panicles.(Taddy,2004).

Fig.2 Cono weeder

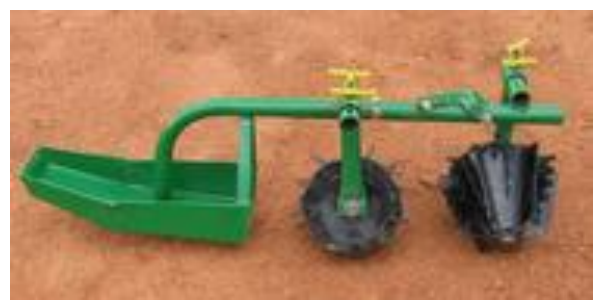

Flow Chart Of Handed Over Of Paddy Drum Seeder Technology To The Farmers

Wide publicity through Press \& Media

Selection farmers

Training

$\downarrow$

Method Demonstrations \& On Farm Trials

$\downarrow$

Monitoring \& supervision

Data recording \& analysis \& evaluation 
Table.1 Mean data on Yield and Yield attributes of On-Farm Demonstrations on paddy drum seeder technology conducted from Kharif-2011 to kharif,2013

\begin{tabular}{|c|c|c|c|c|c|c|c|c|c|c|}
\hline \multirow[t]{2}{*}{ Season } & \multirow[t]{2}{*}{$\begin{array}{l}\text { No.of } \\
\text { Locations }\end{array}$} & \multicolumn{2}{|c|}{ Duration } & \multicolumn{2}{|c|}{$\begin{array}{l}\text { No.of } \\
\text { Productive } \\
\text { tillers/Sq.mt }\end{array}$} & \multicolumn{2}{|c|}{$\begin{array}{l}\text { No.of } \\
\text { grains/panicle }\end{array}$} & \multicolumn{2}{|c|}{ Yield Kg/ha } & \multirow{2}{*}{$\begin{array}{l}\text { Percentage } \\
\text { Increase } \\
\text { over } \\
\text { Check }\end{array}$} \\
\hline & & Demo & Check & Demo & Check & Demo & Check & Demo & Check & \\
\hline $\begin{array}{l}\text { Kharif- } \\
2011\end{array}$ & 5 & 128 & 138 & 265 & 224 & 221 & 198 & 6318 & 5893 & 7.22 \\
\hline $\begin{array}{l}\text { Kharif- } \\
2012\end{array}$ & 5 & 131 & 143 & 274 & 222 & 247 & 207 & 6274 & 5579 & 12.46 \\
\hline \multirow{2}{*}{$\begin{array}{l}\text { Kharif- } \\
2013\end{array}$} & 5 & 124 & 145 & 262 & 214 & 232 & 202 & 6232 & 5263 & 18.41 \\
\hline & 5 & 128 & 142 & 267 & 220 & 233 & 202 & 6275 & 5578 & 12.49 \\
\hline
\end{tabular}

Table.2 Mean of comparative analysis of cost of cultivation including labour per hectare of paddy

\begin{tabular}{|c|c|c|c|c|c|}
\hline \multirow[t]{2}{*}{ SI.No } & \multirow[t]{2}{*}{ Practice } & \multicolumn{2}{|c|}{ Paddy drum seeder technology } & \multicolumn{2}{|c|}{$\begin{array}{l}\text { Conventional transplantation } \\
\text { method }\end{array}$} \\
\hline & & No.of labour & Cost in Rs. & No.of labour & Cost in Rs. \\
\hline \multirow[t]{2}{*}{1.} & Land preparation for nursery & 0 & 0 & $\begin{array}{l}\text { Ploughing } \\
\text { charges }\end{array}$ & 1875 \\
\hline & $\begin{array}{l}\text { Land preparation of } \\
\text { main field }\end{array}$ & $\begin{array}{l}8 \mathrm{M} \& \text { Puddling } \\
\text { charges }\end{array}$ & 5600 & $\begin{array}{l}\text { 8M\& Puddling } \\
\text { charges }\end{array}$ & 5600 \\
\hline 2. & Nursery Management & 0 & 0 & $5 \mathrm{M} \& 5 \mathrm{~F}$ & 1750 \\
\hline 3. & Transplanting & 0 & 0 & $20 \mathrm{M} \& 25 \mathrm{~F}$ & 7750 \\
\hline 4. & Manures \& Fertilizers & $15 \mathrm{M}$ & 8670 & $15 \mathrm{M}$ & 7260 \\
\hline 5. & $\begin{array}{l}\text { Weeding \& Herbicde } \\
\text { Inter-cultivation }\end{array}$ & $\begin{array}{l}5 \mathrm{M} \& \\
10 \mathrm{~F}\end{array}$ & 3000 & $25 \mathrm{~F}$ & 3750 \\
\hline 6. & Plant protection \& Chemicals & $2 \mathrm{M} \& 2 \mathrm{~F}$ & 2000 & $4 \mathrm{M} \& 4 \mathrm{~F}$ & 2000 \\
\hline 7. & Irrigation management & $10 \mathrm{M}$ & 2000 & $8 \mathrm{M}$ & 1600 \\
\hline 8. & Harvesting & $40 \mathrm{~F}$ & 6000 & $30 \mathrm{~F}$ & 4500 \\
\hline \multirow[t]{2}{*}{9.} & $\begin{array}{l}\text { Threshing, Winnowing and } \\
\text { bagging }\end{array}$ & $\begin{array}{l}25 \mathrm{M} \& \\
25 \mathrm{~F}\end{array}$ & 12600 & $\begin{array}{l}20 \mathrm{M} \& \\
20 \mathrm{~F}\end{array}$ & 10500 \\
\hline & Total & $\begin{array}{l}65 \mathrm{M} \& \\
77 \mathrm{~F}\end{array}$ & 39870 & $\begin{array}{l}80 \mathrm{M} \& \\
109 \mathrm{~F}\end{array}$ & 46585 \\
\hline
\end{tabular}


Table.3 Economics of the Paddy Drum seeder technology vs Normal transplantation method of Kharif,2011 to 2013 seasons

\begin{tabular}{|c|c|c|c|c|c|}
\hline SI.No & Particulars & Demonstration & Check & Difference & $\begin{array}{l}\text { Percentage } \\
\text { increase or } \\
\text { decrease }\end{array}$ \\
\hline 1 & Grain Yield Kg/ha & 6275 & 5578 & 697 & 12.49 \\
\hline 2 & Straw Yield $\mathrm{Kg} / \mathrm{ha}$ & 7530 & 6696 & 834 & 12.45 \\
\hline 3 & Grain Value (Rs.13/kg) & 81575 & 66936 & 14639 & 21.87 \\
\hline 4 & Straw Value (Rs.0.5/kg) & 3765 & 3348 & 417 & 12.45 \\
\hline 5 & Gross income Rs./ha & 85340 & 75862 & 9478 & 12.49 \\
\hline 6 & $\begin{array}{l}\text { Total cost of cultivation } \\
\text { Rs./ha }\end{array}$ & 39870 & 46585 & -6715 & -14.41 \\
\hline 7 & Net income Rs./ha` & 45470 & 29277 & 16193 & 61.62 \\
\hline 8 & $\mathrm{C}: \mathrm{B}$ ratio & 2.14 & 1.62 & 0.52 & 32.09 \\
\hline
\end{tabular}

\section{Labour involvement in Rice cultivation}

There is reduction in laobur utilization (Table 2) is observed in drum seeder technology i.e., 15 man labour and 32 women labour when compared to normal method of transplanting method.

Additional grain yield and straw yield (Table.3) of $697 \mathrm{Kgha}^{-1}$ and $834 \mathrm{Kgha}^{-1}$ recorded in drum seed technology compared with normal practice of transplantation, this could be due to uniform plant population, good tillering capacity. Additional net income of Rs.16193 ha ${ }^{-1}$ received in drum seeder technology with reduction of cost of cultivation of Rs. $6715 \mathrm{ha}^{-1}$ realized over normal transplanting.

The results from the study showed that the farmers realized the $61.62 \%$ increase in net income due to increased grain yield by $12.49 \%$ with reduction of cost of cultivation by $14.41 \%$, it could be attributed to reduction in manual labour of 15 man labour and 32 women labour and also increase in yield attributes and yield (Paladugu et al.,2004).

\section{References}

Annual reports of Indian Institute of Rice Research, 2003, Rajendranagar, Hyderabad.

Krishnaiah K, 1999. Rice production in IndiaCREMNET status and future concerns. Paper presented at $2^{\text {nd }}$ CREMNET Workshop-cum-Group Meeting, 24-27, August 1999, SWMRI, Thanjavur, India.

MSSRF,2002, The System of Rice Intensification-SRI, In: Updateson SRI activities/Progress around the world, CIIFAD Report, April, 2004. In: http://ciifad.cornell.edu/sri

Paladugu S, Thati S, Lekhi M, Yadla S, Poli R and Alapati S, 2004 Studies on vareital performance under SRI and non-SRI. World Rice Research Conference, Nov (5-7), 2004 HELD AT Tsukuba International Congress Centres (Epochas, Tsukuba), Tsukuba, Ibaraki, Japan Section-26 : pp553.

The Hindu Survey of Indian Agriculture, 2006 pp.5-54. 


\section{How to cite this article:}

Srinivasa Rao, M. M. V. and Chinnam Naidu, D. 2019. Drum Seeder Technology is Made Easy Paddy Cultivation and it is a Boon to Farmers of North Coastal Zone of Andhra Pradesh. Int.J.Curr.Microbiol.App.Sci. 8(09): 17331739. doi: https://doi.org/10.20546/ijcmas.2019.809.200 